\title{
Description of Maribacter forsetii sp. nov., a marine Flavobacteriaceae isolated from North Sea water, and emended description of the genus Maribacter
}

\author{
Correspondence \\ Tristan Barbeyron \\ barboun@sb-roscoff.fr \\ Rudolf Amann \\ ramann@mpi-bremen.de
}

\author{
Tristan Barbeyron, ${ }^{1}$ Flavien Carpentier, ${ }^{1}$ Stéphane L'Haridon, ${ }^{2}$ \\ Margarete Schüler, ${ }^{3}$ Gurvan Michel ${ }^{1}$ and Rudolf Amann ${ }^{3}$
}

\author{
${ }^{1}$ Centre National de la Recherche Scientifique; Université Pierre et Marie Curie-Paris 6, Unité Mixte \\ de Recherche 7139 'Végétaux Marins et Biomolécules', Station Biologique, F-29682 Roscoff \\ Cedex (Bretagne), France \\ ${ }^{2}$ Centre National de la Recherche Scientifique; Université de Bretagne Occidentale, IFREMER, \\ Unité Mixte de Recherche 6197 'Laboratoire de Microbiologie des Environnements Extrêmes', \\ IFREMER, F-29280 Plouzané (Bretagne), France \\ ${ }^{3}$ Max-Planck-Institut für Marine Mikrobiologie, D-28359 Bremen, Germany
}

\begin{abstract}
Three rod-shaped, Gram-negative, chemo-organotrophic, heterotrophic, strictly aerobic, gliding bacterial strains, KT02ds18-4, KT02ds18-5 and KT02ds18-6 ${ }^{\top}$, were isolated from North Sea surface waters near the island of Helgoland, Germany. Their taxonomic position was investigated by a polyphasic approach. The three strains were light yellow, oxidase- and catalase-positive, and grew optimally at $25{ }^{\circ} \mathrm{C}$, at $\mathrm{pH} 7.5$, and in the presence of $2.5 \%(\mathrm{w} / \mathrm{v}) \mathrm{NaCl}$. The Chargaff's coefficient was 34.2-34.4 mol\%. The three strains shared $>90 \%$ DNA-DNA relatedness and an identical 16S rRNA gene sequence. Comparative 16S rRNA gene sequence analysis allocated the three strains to the genus Maribacter in the family Flavobacteriaceae, with similarities of 97.0-97.4\% to five of the recognized Maribacter species. Their low level of DNA-DNA relatedness $(<20 \%)$ with these species and differentiating phenotypic characteristics demonstrated that they constitute a new Maribacter species for which the name Maribacter forsetii sp. nov. is proposed. Strain KT02ds18-6 ${ }^{\top}\left(=\right.$ CIP $109504^{\top}=$ DSM $\left.18668^{\top}\right)$ is the type strain. An emended description of the genus Maribacter is also proposed.
\end{abstract}

The Cytophaga-Flavobacterium cluster within the phylum Bacteroidetes often accounts for more than $10 \%$ of the total microbial community in coastal and offshore waters (Glöckner et al., 1999; Abell \& Bowman, 2005; DeLong et al., 2006). Moreover, flavobacteria have been found in high abundance during natural and induced phytoplankton blooms, suggesting utilization of polymeric organic matter in marine systems (Kirchman, 2002). This characteristic was recently confirmed by whole-genome sequence analysis of the first marine Bacteroidetes, 'Gramella forsetii strain $\mathrm{KT}_{0803}{ }^{\mathrm{T}}$ (Bauer et al., 2006) isolated from the North Sea.

In this study, we report the polyphasic characterization of strains KT02ds18-4, KT02ds18-5 and KT02ds18-6 ${ }^{\mathrm{T}}$ isolated

The GenBank/EMBL/DDBJ accession numbers for the 16S rRNA gene sequences of Maribacter forsetii KT02ds18-4, KT02ds18-5 and KT02ds $18-6^{\top}$ are AM712898, AM712899 and AM712900, respectively.

Electron micrographs of strain $\mathrm{KTO} 2 \mathrm{ds} 18-6^{\top}$ are available with the online version of this paper. from seawater sampled at the same location as 'Gramella forsetii', as a new species of the genus Maribacter in the family Flavobacteriaceae (Bernardet et al., 1996, 2002), phylum Bacteroidetes. The genus Maribacter initially contained four species: Maribacter aquivivus, Maribacter orientalis, Maribacter ulvicola and the type species Maribacter sedimenticola was isolated from marine sediment, water and algae (Nedashkovskaya et al., 2004). A fifth species, Maribacter dokdonensis, was described from seawater (Yoon et al., 2005). The comparative study of our isolates with these five Maribacter species allows us to also provide an emended description of the genus Maribacter.

Strain KT02ds18 was isolated from a North Sea water sample taken on 25 August 1999 at a depth of $1 \mathrm{~m}$ at station Kabeltonne, also known as Helgoland Roads $\left(54^{\circ} 11^{\prime} \mathrm{N} ; 7^{\circ} 54^{\prime} \mathrm{E}\right)$. Isolation was performed on an oligotrophic synthetic seawater medium (Schut et al., 1993) containing a mixture of defined monomeric sugars (at $10 \mu \mathrm{M}$ ), amino acids (at $1 \mu \mathrm{M}$ ) and acetate, lactate, ethanol and glycerol (all at $15 \mu \mathrm{M}$ ) with reduced $\mathrm{NH}_{4} \mathrm{Cl}$ 
and $\mathrm{KH}_{2} \mathrm{PO}_{4}$ concentrations of 50 and $1.5 \mu \mathrm{M}$, respectively (Eilers, 2000). Upon subcultivation on ZoBell agar 2216E (ZoBell, 1941), strain KT02ds18 was shown to actually consist of three different strains, KT02ds18-4, KT02ds18-5 and KT02ds18-6 ${ }^{\mathrm{T}}$, distinguished on the basis of different colony morphology. For direct comparison, Maribacter aquivivus $\mathrm{KMM} 3949^{\mathrm{T}}$, M. orientalis $\mathrm{KMM} 3947^{\mathrm{T}}$, M. sedimenticola KMM $3903^{\mathrm{T}}$, M. ulvicola KMM $3951^{\mathrm{T}}$ and $M$. dokdonensis DSM $17201^{\mathrm{T}}$ were studied in parallel with the isolates in all phenotypic tests (except growth at different temperatures, $\mathrm{pH}$ and $\mathrm{NaCl}$ concentrations) and whole-cell protein analysis. All strains were routinely cultivated in liquid or on solid (solidified with $1.5 \%$, w/v, agar) ZoBell medium 2216E (ZoBell, 1941). Pure cultures were stored at $-80{ }^{\circ} \mathrm{C}$ in culture medium containing $20 \%$ (v/v) glycerol.

Growth was monitored by the increase in optical density at $600 \mathrm{~nm}$ using a UV1601 spectrophotometer (Shimadzu). All growth experiments were performed in triplicate. The optimal $\mathrm{pH}$ value was determined in Cytophaga marine broth no. 172 (DSMZ) using $10 \mathrm{mM}$ MES buffer at $\mathrm{pH}$ 5.0, 5.5 and 6.0, $10 \mathrm{mM}$ PIPES buffer at $\mathrm{pH} 6.5$ and 7.0, $10 \mathrm{mM}$ HEPES buffer at $\mathrm{pH} 7.5,10 \mathrm{mM}$ Tris/ $\mathrm{HCl}$ at $\mathrm{pH} 8.0$ and 8.5 , and no buffer at $\mathrm{pH} 9.0$. The effect of $\mathrm{NaCl}$ on growth was determined in the same medium containing $0-9 \%(\mathrm{w} / \mathrm{v})$ $\mathrm{NaCl}$ at $1 \%$ intervals. The temperature range for growth was determined at $4,10,15,20,25,32$ and $37{ }^{\circ} \mathrm{C}$. The effects of $\mathrm{pH}$ and $\mathrm{NaCl}$ concentration were determined at $25{ }^{\circ} \mathrm{C}$. Cell morphology and gliding motility were investigated on an exponential ZoBell broth culture at $20{ }^{\circ} \mathrm{C}$ by phase-contrast microscopy (Olympus $\mathrm{BH} 2$ microscope, $\times 1000$ magnification). Gram staining was carried out according to the method described by Doetsch (1981). For transmission electron microscopy, $20 \mu \mathrm{l}$ of a bacterial suspension was dropped onto carbon-coated grids (400 mesh) and negatively stained with $2 \%(\mathrm{w} / \mathrm{v})$ uranyl acetate or $2 \%(\mathrm{v} / \mathrm{v})$ phosphotungstic acid for $1 \mathrm{~min}$. Micrographs were taken on a model CM12 electron microscope (Philips) with an acceleration voltage of $100 \mathrm{kV}$. To determine the respiratory type of metabolism, the bacteria were inoculated in Veillon's tubes containing ZoBell medium solidified with $0.6 \%(\mathrm{w} / \mathrm{v})$ agar. Oxygen was removed from the medium by boiling. To determine oxidative or fermentative metabolism, the strains were inoculated in a modified Leifson O-F medium (Hugh \& Leifson, 1953; Smibert \& Krieg, 1981) containing $0.5 \%$ (w/v) glucose. Cytochrome oxidase activity was assayed by vigorous shaking of cells from a $2.5 \mathrm{ml}$ broth culture for $5 \mathrm{~min}$ in $0.5 \mathrm{ml}$ natural seawater and in the presence of $20 \mu \mathrm{l}$ dimethyl-p-phenylenediamineoxalate (bioMérieux). The presence of the enzyme was revealed by a blue coloration of the cell suspension. Catalase activity was assayed by mixing one colony from a ZoBell agar plate with a drop of hydrogen peroxide $(10 \%, \mathrm{v} / \mathrm{v})$. Amylase activity was assayed on $0.2 \%$ $(\mathrm{w} / \mathrm{v})$ soluble starch ZoBell agar plates. DNase activity was detected in DNA agar (Difco), prepared with seawater. Amylase and DNase activities were revealed by flooding the plates with Lugol solution or $1 \mathrm{M} \mathrm{HCl}$, respectively. Agarase, $\kappa$-carrageenase and $l$-carrageenase activities were assessed by inoculating ZoBell media solidified with $15 \mathrm{~g}$ agar $\mathrm{l}^{-1}$, $10 \mathrm{~g} \kappa$-carrageenan $\mathrm{l}^{-1}$ or $20 \mathrm{~g} l$-carrageenan $\mathrm{l}^{-1}$, respectively. Strains whose colonies were surrounded by a depression in the substrate were considered positive. Production of flexirubin-type pigments was assessed by flooding a 4-day-old plate culture with $20 \%(\mathrm{w} / \mathrm{v})$ potassium hydroxide, followed by the observation of changes in colony colour from yellow to red or brown (Reichenbach et al., 1974). The ability to use simple carbohydrates as carbon sources was tested in artificial seawater supplemented with $2 \mathrm{~g}$ ammonium nitrate $\mathrm{l}^{-1}, 250 \mathrm{mg}$ Casamino acids $\mathrm{l}^{-1}$, $150 \mathrm{mg}$ yeast extract $1^{-1}$ and the carbohydrate under investigation at a concentration of $0.5 \%(\mathrm{w} / \mathrm{v})$. Other tests were performed by using the identification strips API $20 \mathrm{NE}$ (with API AUX medium), API ZYM and API $50 \mathrm{CH}$ (bioMérieux). The latter were used both in the acidification and assimilation modes, using API 50CHB/E medium and a medium containing $2 \mathrm{~g}$ ammonium sulfate $\mathrm{l}^{-1}, 100 \mathrm{mg}$ yeast extract $1^{-1}$ and $1.5 \mathrm{~g}$ agar $\mathrm{l}^{-1}$ in $40 \mathrm{mM}$ phosphate buffer, $\mathrm{pH} 8$, respectively. All culture media were supplemented up to $25 \mathrm{~g} \mathrm{NaCl} \mathrm{l}^{-1}$. GN2 microplates (Biolog) were inoculated with bacterial suspensions in a medium containing $25 \mathrm{~g}$ $\mathrm{NaCl} \mathrm{l}^{-1}, 8 \mathrm{~g} \mathrm{MgCl}_{2} \mathrm{l}^{-1}$ and $0.5 \mathrm{~g} \mathrm{KCl} \mathrm{l}^{-1}$, supplemented with $1.5 \mathrm{~g} l$-carrageenan $\mathrm{l}^{-1}$. API galleries and GN2 microplates were incubated at $20{ }^{\circ} \mathrm{C}$ for 2 weeks. Sensitivity to chloramphenicol $\left(10 \mu \mathrm{g} \mathrm{ml}^{-1}\right)$, penicillin $\mathrm{G}$ $\left(200 \mu \mathrm{g} \mathrm{ml}^{-1}\right)$, streptomycin $\left(200 \mu \mathrm{g} \mathrm{m}{ }^{-1}\right)$, kanamycin $\left(200 \mu \mathrm{g} \mathrm{ml}^{-1}\right)$, ampicillin $\left(200 \mu \mathrm{g} \mathrm{ml}^{-1}\right)$, rifampicin $(10 \mu \mathrm{g}$ $\left.\mathrm{ml}^{-1}\right)$ and tetracycline $\left(10 \mu \mathrm{g} \mathrm{ml}^{-1}\right)$ (all from Sigma) was tested at $20{ }^{\circ} \mathrm{C}$ in Cytophaga marine broth.

The fatty acid composition of the three isolates was determined by the DSMZ, according to the standard protocol of the MIDI Microbial Identification System (Sasser, 1990), on cells grown on TSBA40 (30 g trypticase soy broth $\mathrm{l}^{-1}$ and $15 \mathrm{~g}$ agar $\mathrm{l}^{-1}$ ) at $28{ }^{\circ} \mathrm{C}$ for $24 \mathrm{~h}$. Cellular proteins were extracted from cell pellets from a $2.0 \mathrm{ml} 24 \mathrm{~h}$ ZoBell broth culture at $25^{\circ} \mathrm{C}$. Cells were washed twice with artificial seawater and resuspended in $375 \mu \mathrm{l}$ BugBuster Protein Extraction Reagent (Novagen). The cells were disrupted by vigorous shaking and kept on ice for $10 \mathrm{~min}$. Proteins were denatured for $5 \mathrm{~min}$ at $100{ }^{\circ} \mathrm{C}$ in the presence of $125 \mu \mathrm{l} 4 \times$ loading buffer $(60 \mathrm{mM}$ Tris/HCl, pH 6.8, 2\% SDS, $0.005 \%$, w/v, bromophenol blue, $1.4 \mathrm{M}$ $\beta$-mercaptoethanol). The amounts of protein loaded onto an SDS-PAGE gel $(20 \times 20 \mathrm{~cm}, 1.5 \mathrm{~mm}$ thick; $12 \%$, w/v, polyacrylamide in running gel, $4 \%$ in stacking gel) were standardized with respect to the strain that had the lowest optical density. The Chargaff's coefficient of the DNA, expressed as the molar percentage of guanine + cytosine $(\mathrm{mol} \% \mathrm{G}+\mathrm{C})$, was determined by the DSMZ. Genomic DNAs were obtained by using the procedure described by Barbeyron et al. (1984). DNA was purified on a $\mathrm{CsCl}_{2}$ gradient and purity was checked spectrophotometrically. The 16S rRNA gene sequence was amplified by PCR using pure genomic DNA as template and a couple of primers specific for Bacteria, 8F (Hicks et al., 1992) and 1492R (Kane et al., 1993). PCR reactions were typically carried out 
in a volume of $50 \mu \mathrm{l}$ containing 10-100 ng template, $0.4 \mu \mathrm{M}$ each specific primer, $250 \mu \mathrm{M}$ each dNTPs, $0.1 \mathrm{mg}$ BSA, $1 \times$ GoTaq buffer (Promega) and $1.25 \mathrm{U}$ GoTaq DNA polymerase (Promega). The PCR conditions were as follows: $2 \mathrm{~min}$ at $95{ }^{\circ} \mathrm{C}$, followed by 30 cycles of $0.5 \mathrm{~min}$ at $95{ }^{\circ} \mathrm{C}$, $0.5 \mathrm{~min}$ at $50{ }^{\circ} \mathrm{C}, 1.5 \mathrm{~min}$ at $72{ }^{\circ} \mathrm{C}$ and a final polymerization step of 4 min at $72{ }^{\circ} \mathrm{C}$. PCR products were purified with the MinElute PCR purification kit (Qiagen), cloned into vector pCRII2.1 and sequenced using BigDye-labelled dideoxyribonucleotides, the Thermosequenase kit (RPN 2444; Amersham) and an ABI PRISM 3130xl Genetic Analyzer automated sequencer (Applied Biosystems/Hitachi). The $16 \mathrm{~S}$ rRNA gene sequences of strains KT02ds18-4, KT02ds18-5 and KT02ds18- $6^{\mathrm{T}}$ were aligned manually with a representative set of sequences obtained from GenBank (Benson et al., 1999). The secondary structure was used as a guide to ensure that only homologous regions were compared. Of the 1383 nt that were sequenced, 1286 were used in the phylogenetic analysis. A modified version of the neighbour-joining algorithm (Saitou \& Nei 1987; Gascuel, 1997) was used with the Kimura distance correction (Kimura, 1980) and bootstrap analysis was performed to provide confidence estimates for the phylogenetic tree topologies (Felsenstein, 1985). The maximum-parsimony (Fitch, 1971) and maximum-likelihood (Felsenstein, 1981) methods were also applied, as implemented in the PHYLO_WIN package (Galtier et al., 1996). Genetic relatedness was investigated by slot-blot DNA-DNA hybridization, using the ECF random-prime labelling and signal amplification system (ECF kit RPN 5752; Amersham Life Sciences), following the procedure described by Kristjánsson et al. (1994). Target DNA (50 ng) denatured in $0.4 \mathrm{M} \mathrm{NaOH}$ was slotted onto a nylon hybridization membrane (Bio-Rad) and probed with 200 ng fluoresceinlabelled tracer DNA. For each duplicate of DNA-DNA association, the hybridization temperature was chosen in the optimal range of the hybridization buffer (Johnson, 1984; Ivanova et al., 1988).

Strains KT02ds18-4, KT02ds18-5 and KT02ds18-6 ${ }^{\mathrm{T}}$ grew on ZoBell agar plates forming round, shiny, light yellow colonies, $1-3 \mathrm{~mm}$ in diameter within 3 days at $20{ }^{\circ} \mathrm{C}$. The three strains displayed a varying degree of spreading at the margin of their colonies. Colony margins of strain KT02ds18-4 were entire with only very limited spreading (Fig. 1a); those of KT02ds18-5 showed active spreading (Fig. 1b); while the intense spreading of strain KT02ds18$6^{\mathrm{T}}$ resulted in confluent colonies (Fig. 1c). In comparison, other species of Maribacter, grown under the same conditions, showed circular, non-spreading, shiny and dark yellow colonies. Phase-contrast microscopy of wet mounts revealed that all strains were round-ended rods of about $0.3-0.5 \mu \mathrm{m}$ in diameter and $3.0-4.0 \mu \mathrm{m}$ in length occurring singly or in pairs (Fig. 1d). Shorter cells $(1.0 \mu \mathrm{m}$ long) and non-refractive spherical bodies appeared in stationary-phase cultures. Electron micrographs of phosphotungstic acid-coloured cells showed vesicle-like structures that seemed to stem from the outer membrane (see supplementary Fig. S1, available with the online version of

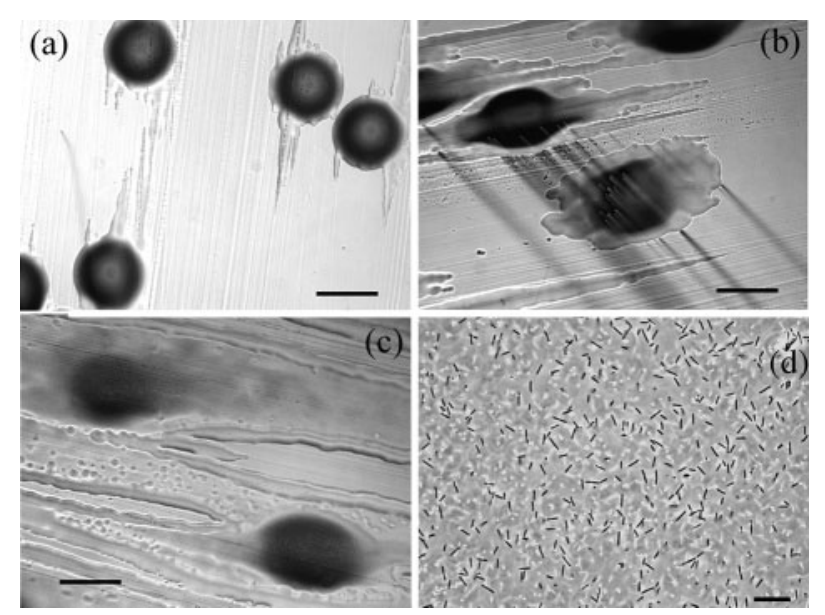

Fig. 1. Colonies of KT02ds18-4 (a), KT02ds18-5 (b) and KT02ds18-6 ${ }^{\top}$ (c) on ZoBell agar after 5 days incubation at $25{ }^{\circ} \mathrm{C}$. Note the difference in the extent of spreading. (d) Phasecontrast micrograph of strain KT02ds18- $6^{\top}$ cultivated in ZoBell Broth for $24 \mathrm{~h}$ at $25{ }^{\circ} \mathrm{C}$. Bars, (a, b, c) $1 \mathrm{~mm}$; (d) $10 \mu \mathrm{m}$.

this paper). The three strains were non-flagellated, adhered to the slide and to the cover glass, and displayed active gliding motility. Strain KT02ds $18-6^{\mathrm{T}}$ was the most active. All strains were Gram-negative, strictly aerobic, chemo-organotrophic and heterotrophic organisms with an oxidative metabolism that used oxygen as electron acceptor. Nitrate could not be used as electron acceptor. Cytochrome oxidase and catalase were positive and flexirubin-type pigments were not synthesized. Additional phenotypic characteristics of strains KT02ds18-4, KT02ds18-5 and KT02ds18-6 ${ }^{\mathrm{T}}$ are given in the species description and in Table 1 . Overall, the results obtained in this study with five Maribacter species are in agreement with previously published data (Nedashkovskaya et al., 2004; Yoon et al., 2005). The few exceptions may have resulted from different cultivation conditions or different phenotypic tests. The major discrepancies with the original description of the genus Maribacter and the five Maribacter species in this study are: (i) agarase activity was not detected in any strain; (ii) DNA hydrolysis was detected in all species except $M$. aquivivus; and (iii) although tested several times (five experiments), none of the species was able to reduce nitrate to nitrite in API 20 NE strips (a result confirmed using the Greiss reagent and strain Zobellia galactanivorans $\mathrm{Dsij}^{\mathrm{T}}$ as positive control; Barbeyron et al., 2001). Moreover, in contrast with the statements of Nedashkovskaya et al. (2004) and Yoon et al. (2005), strains KT02ds18-4, KT02ds18-5 and KT02ds18- $6^{\mathrm{T}}$ were able to grow, albeit weakly, in the absence of $\mathrm{NaCl}$. Consequently, we have proposed an emended description of the genus Maribacter (see below).

The three isolates showed very similar whole-cell protein profiles, whereas the profiles of the type strains of other Maribacter species were significantly different (Fig. 2). The fatty acid profiles of strains KT02ds18-4, KT02ds18-5 and KT02ds $18-6^{\mathrm{T}}$ were also very similar (Table 2), featuring 


\section{Table 1. Phenotypic characteristics of Maribacter species}

Species: 1, Maribacter forsetii sp. nov. (3 strains); 2, M. aquivivus KMM $3949^{\mathrm{T}} ; 3$, M. dokdonensis DSM $17201^{\mathrm{T}} ; 4$, M. orientalis KMM $3947^{\mathrm{T}}$; 5, M. sedimenticola KMM 3903 ${ }^{\mathrm{T}}$; 6, M. ulvicola KMM $3951^{\mathrm{T}}$. All strains are Gram-negative, non-flagellated and rod-shaped. All strains were positive for the following characteristics: respiratory metabolism; gliding motility; presence of cytochrome oxidase, catalase, alkaline and acid phosphatases, leucine, valine and cystine arylamidases and $\alpha$-chymotrypsine activities; hydrolysis of aesculin and dextrin; utilization of D-xylose, cellobiose, maltose, sucrose, trehalose and aspartic acid; and acid production from glucose and sucrose. All strains were negative for the following characteristics: presence of $\beta$-glucuronidase acivity; hydrolysis of agar, $\kappa$-carrageenan, glycogen and inulin; production of flexirubin pigments; nitrate reduction; utilization of $\mathrm{D}$-arabinose, $\mathrm{D}$-tagatose, $\mathrm{L}$-xylose, $\mathrm{D}$-fucose, L-sorbose, D-ribose, D-lyxose, L-arabitol, adonitol, xylitol, dulcitol, and D-sorbitol; and production of acid from D-tagatose, L-xylose, Dfucose, L-sorbose, D-ribose, D-lyxose, glycerol, L-erythritol, D- and Larabitol, adonitol, xylitol, dulcitol, D-mannitol, D-sorbitol, inositol, glycogen and inulin. +, Positive; -, negative; $\mathrm{w}$, weakly positive; $\mathrm{V}$, variable; ND, not determined.

\begin{tabular}{|c|c|c|c|c|c|c|}
\hline Characteristic & $1^{\star}$ & 2 & 3 & 4 & 5 & 6 \\
\hline $\begin{array}{l}\text { Optimal growth } \\
\text { temperature }\left({ }^{\circ} \mathrm{C}\right)\end{array}$ & 25 & $22 \dagger$ & $30 \ddagger$ & $22 \dagger$ & $23 \dagger$ & $22 \dagger$ \\
\hline \multicolumn{7}{|l|}{ Growth at/with: } \\
\hline $6 \%(\mathrm{w} / \mathrm{v}) \mathrm{NaCl}$ & + & $+\dagger$ & $+\ddagger$ & $-\dagger$ & $+\dagger$ & $-\dagger$ \\
\hline $32{ }^{\circ} \mathrm{C}$ & + & $-\dagger$ & $+\ddagger$ & $+\dagger$ & $+\dagger$ & $+\dagger$ \\
\hline \multicolumn{7}{|l|}{ Presence of: } \\
\hline Esterase (C4) & + & - & + & - & - & - \\
\hline Esterase lipase (C8) & + & - & + & + & - & - \\
\hline Lipase (C14) & $\mathrm{v}(-)$ & - & - & - & - & - \\
\hline Trypsin & $\mathrm{v}(-)$ & + & + & + & + & + \\
\hline $\begin{array}{l}\text { Naphthol-AS-BI- } \\
\text { phosphatase }\end{array}$ & + & + & + & - & - & - \\
\hline$\alpha$-Galactosidase & + & - & - & - & - & - \\
\hline$\beta$-Galactosidase & + & + & + & + & - & + \\
\hline$\alpha$-Glucosidase & + & + & + & - & - & + \\
\hline$\alpha$-Fucosidase & $\mathrm{V}(-)$ & - & - & - & - & - \\
\hline \multicolumn{7}{|l|}{ Hydrolysis of: } \\
\hline l-Carrageenan & - & + & + & + & - & + \\
\hline Starch & - & - & - & - & + & - \\
\hline Alginic acid & + & + & $\mathrm{ND}$ & + & + & + \\
\hline Gelatin & - & + & - & - & + & - \\
\hline DNA & - & - & + & + & + & + \\
\hline Tween 40 & + & - & + & - & - & + \\
\hline Tween 80 & + & - & + & - & - & - \\
\hline \multicolumn{7}{|l|}{ Utilization of: } \\
\hline D-Mannose & + & + & + & + & - & + \\
\hline D-Fructose & + & + & + & - & + & + \\
\hline Glycerol & - & - & + & - & - & - \\
\hline D-Mannitol & + & + & + & + & - & + \\
\hline D-Lactose & + & + & + & + & - & + \\
\hline Amygdalin & - & + & - & - & - & - \\
\hline Turanose & $\mathrm{v}(+)$ & + & + & + & - & + \\
\hline
\end{tabular}

Table 1. cont.

\begin{tabular}{|c|c|c|c|c|c|c|}
\hline Characteristic & $1^{\star}$ & 2 & 3 & 4 & 5 & 6 \\
\hline Melezitose & $\mathrm{v}(+)$ & + & + & - & - & - \\
\hline Methyl- $\beta$-D-glucoside & + & + & + & - & - & - \\
\hline Methyl- $\beta$-D-xyloside & + & + & $\mathrm{w}$ & - & - & $\mathrm{W}$ \\
\hline$N$-acetyl-D-glucosamine & + & + & + & + & - & + \\
\hline Glucuronic acid & + & + & - & + & $\mathrm{W}$ & + \\
\hline Lactic acid & + & - & - & + & - & + \\
\hline Succinic acid & $\mathrm{v}(-)$ & + & - & + & - & + \\
\hline L-Alanine & $\mathrm{v}(-)$ & - & + & + & - & + \\
\hline \multicolumn{7}{|l|}{ Acid production from: } \\
\hline D-Galactose & + & + & + & + & - & + \\
\hline D-Mannose & + & - & + & + & - & + \\
\hline D-Fructose & + & $\mathrm{w}$ & - & + & + & + \\
\hline D-Arabinose & + & - & + & - & - & + \\
\hline L-Arabinose & - & - & - & $\mathrm{w}$ & - & - \\
\hline D-Xylose & + & + & + & + & - & + \\
\hline L-Rhamnose & - & - & - & - & - & $\mathrm{w}$ \\
\hline L-Fucose & + & - & + & - & - & - \\
\hline Cellobiose & + & - & + & + & - & + \\
\hline D-Lactose & + & - & + & + & - & + \\
\hline Maltose & + & - & + & + & + & + \\
\hline Melibiose & $\mathrm{v}(+)$ & - & + & + & - & + \\
\hline Trehalose & $\mathrm{v}(+)$ & + & + & + & $\mathrm{W}$ & + \\
\hline Gentiobiose & $\mathrm{v}(+)$ & - & $\mathrm{w}$ & - & - & - \\
\hline Amygdalin & $\mathrm{v}(+)$ & - & + & + & - & + \\
\hline Turanose & $\mathrm{v}(+)$ & - & + & + & - & - \\
\hline Raffinose & $\mathrm{v}(+)$ & - & + & - & $\mathrm{w}$ & - \\
\hline Starch & - & - & - & - & + & - \\
\hline Methyl- $\alpha$-D-glucoside & $\mathrm{v}(+)$ & - & + & + & - & + \\
\hline Methyl- $\alpha$-D-mannoside & $\mathrm{v}(+)$ & - & + & + & - & + \\
\hline Methyl- $\beta$-D-xyloside & + & - & + & + & - & + \\
\hline$N$-Acetyl-D-glucosamine & $\mathrm{v}(+)$ & - & - & + & - & + \\
\hline Salicin & + & - & + & + & - & + \\
\hline \multicolumn{7}{|l|}{ Susceptibility to antibiotics: } \\
\hline $\begin{array}{l}\text { Penicillin G } \\
\quad\left(200 \mu \mathrm{g} \mathrm{ml}^{-1}\right)\end{array}$ & $\mathrm{v}(+)$ & ND & ND & ND & ND & ND \\
\hline $\begin{array}{l}\text { Streptomycin } \\
\qquad\left(200 \mu \mathrm{g} \mathrm{ml}^{-1}\right)\end{array}$ & $\mathrm{v}(+)$ & ND & ND & ND & ND & $\mathrm{ND}$ \\
\hline Ampicillin $\left(200 \mu \mathrm{g} \mathrm{ml}^{-1}\right)$ & $\mathrm{W}$ & $-\S$ & $-\S$ & $-\S$ & $-\S$ & $+\S$ \\
\hline $\begin{array}{l}\text { Kanamycin } \\
\left(200 \mu \mathrm{g} \mathrm{ml}^{-1}\right)\end{array}$ & - & ND & ND & ND & ND & ND \\
\hline Rifampicin $\left(10 \mu \mathrm{g} \mathrm{ml}^{-1}\right)$ & $\mathrm{v}(+)$ & ND & ND & ND & ND & ND \\
\hline Tetracycline $\left(10 \mu \mathrm{g} \mathrm{ml}^{-1}\right)$ & - & $-\S$ & $\mathrm{w} \ddagger \S$ & $-\S$ & $+\S$ & $-\S$ \\
\hline $\begin{array}{l}\text { Chloramphenicol } \\
\left(10 \mu \mathrm{g} \mathrm{ml}^{-1}\right)\end{array}$ & $\mathrm{v}(+)$ & ND & ND & ND & ND & ND \\
\hline DNA G $+C$ content $(\mathrm{mol} \%)$ & 34.4 & $35 \ddagger$ & $36.1 \neq$ & $39 \neq$ & $37.5 \ddagger$ & $36.7 \ddagger$ \\
\hline
\end{tabular}

${ }^{\star}$ The result of the type strain is given in parentheses.

$\dagger$ Data from Nedashkovskaya et al. (2004).

¥Data from Yoon et al. (2005).

$\S$ Tested by the disc diffusion method; Nedashkovskaya et al. (2003). 


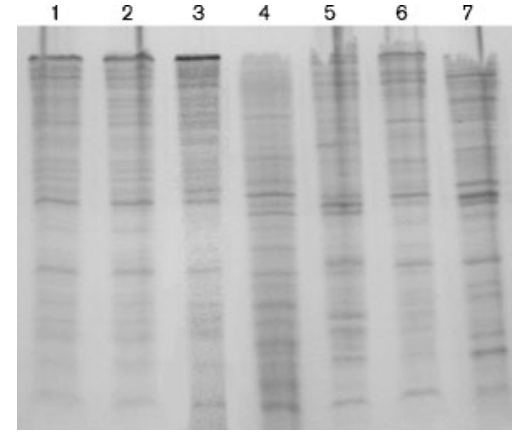

Fig. 2. SDS-PAGE of protein extracts from Maribacter forsetii sp. nov. strains KT02ds18-4 (lane 1), KT02ds18-5 (lane 2) and KT02ds18-6 ${ }^{\top}$ (lane 3), Maribacter aquivivus KMM 3949 ${ }^{\top}$ (lane 4), M. orientalis KMM $3947^{\top}$ (lane 5), M. sedimenticola KMM $3903^{\top}$ (lane 6) and M. ulvicola KMM $3951^{\top}$ (lane 7). Protein bands were visualized by staining with Coomassie blue.

five major fatty acids: $\mathrm{C}_{15: 0}(\approx 15 \%)$, iso- $\mathrm{C}_{15: 0}(\approx 12 \%)$, iso- $\mathrm{C}_{15: 1}(\approx 12 \%)$, iso- $\mathrm{C}_{17: 0} 3-\mathrm{OH}(\approx 18 \%)$ and summed feature 3 (comprising $\mathrm{C}_{16: 1} \omega 7 \mathrm{c}$ and/or iso- $\mathrm{C}_{15: 0} 2-\mathrm{OH}$; $\approx 10 \%)$. These patterns were in accordance with those published for other Maribacter species. However, the respective proportions of some compounds differed, probably as a result of different culture conditions.

The Chargaff's coefficients of the DNA of strains KT02ds184, KT02ds18-5 and KT02ds18-6 ${ }^{\mathrm{T}}$ were $34.2,34.2$ and $34.4 \mathrm{~mol} \%$, respectively. The $16 \mathrm{~S}$ rRNA gene sequences of the strains were identical and shared 97.2, 97.3, 97.4, 97.0 and $97.1 \%$ similarity with those of the $M$. aquivivus, $M$. dokdonensis, M. orientalis, M. sedimenticola and M. ulvicola type strains (over 1404 bp of each sequence), respectively. In the neighbour-joining tree based on $16 \mathrm{~S}$ rRNA gene sequences, the three strains fell within the cluster composed of five other Maribacter species (Fig. 3). Phylogenetic trees generated using the maximum-likelihood method showed essentially the same topology, whereas some differences occurred in the parsimony tree. The $16 \mathrm{~S}$ rRNA gene sequence similarity of the three isolates with the other members of the family Flavobacteriaceae used in the phylogenetic analysis was $<93 \%$. The mean DNA-DNA reassociation level, as determined by slot-blot hybridization, between strains KT02ds18-4, KT02ds18-5 and KT02ds18-6 ${ }^{\mathrm{T}}$ was $90-100 \%$ when their DNAs were used individually as probes for crosshybridization. When the DNAs of the three isolates were used to probe the DNAs of other Maribacter species, or when, reciprocally, the DNAs from Maribacter species were used as probes against the DNAs of the three new strains, DNADNA reassociation levels were $<20-25 \%$, significantly below the values observed at the species level (Stackebrandt \& Goebel, 1994), indicating that strains KT02ds18-4, KT02ds18-5 and KT02ds18-6 ${ }^{\mathrm{T}}$ represent a novel species.

Hence, phylogenetic and fatty acid data show that strains KT02ds18-4, KT02ds18-5 and KT02ds18-6 ${ }^{\mathrm{T}}$ belong to the
Table 2. Whole-cell fatty acid profiles (\%) of Maribacter species

Strains: 1, Maribacter forsetii sp. nov. KT02ds18-6 $6^{\mathrm{T}} ; 2$, M. forsetii sp. nov. KT02ds18-4; 3, M. forsetii sp. nov. KT02ds18-5; 4, M. aquivivus KMM $3949^{\mathrm{T}} ; 5$, M. dokdonensis DSM $17201^{\mathrm{T}} ; 6$, M. orientalis KMM $3947^{\mathrm{T}} ; 7$, M. sedimenticola KMM $3903^{\mathrm{T}} ;$; . M. ulvicola KMM $3951^{\mathrm{T}}$. ND, Not detected; tr, trace $(<1 \%)$. Fatty acids amounting to $<1 \%$ are not listed; therefore, totals do not necessarily reach $100 \%$. Some strains were cultivated under different conditions.

\begin{tabular}{|c|c|c|c|c|c|c|c|c|}
\hline Fatty acid & 1 & 2 & 3 & $4^{\star}$ & $5 \dagger$ & $6^{*}$ & $7^{\star}$ & $8^{*}$ \\
\hline \multicolumn{9}{|l|}{ Straight-chain } \\
\hline $\mathrm{C}_{14: 0}$ & $\operatorname{tr}$ & $\operatorname{tr}$ & $\operatorname{tr}$ & $\operatorname{tr}$ & 1 & $\operatorname{tr}$ & $\operatorname{tr}$ & $\operatorname{tr}$ \\
\hline $\mathrm{C}_{15: 0}$ & 15.5 & 15.5 & 14.7 & 3.8 & 14.5 & 12.3 & 6.3 & 8.1 \\
\hline$C_{16: 0}$ & $\operatorname{tr}$ & 1.0 & 1.0 & 1.4 & $\operatorname{tr}$ & 1.2 & 1.0 & 1.0 \\
\hline \multicolumn{9}{|l|}{ Branched } \\
\hline iso- $\mathrm{C}_{15: 0}$ & 12.4 & 12.5 & 11.9 & 19.7 & 12.3 & 10.6 & 20.5 & 13.6 \\
\hline iso- $\mathrm{C}_{15: 1}$ & 13.2 & 11.7 & 11.1 & 16.1 & 13.6 & 10.1 & 16.9 & 18.9 \\
\hline anteiso- $\mathrm{C}_{15: 0}$ & $\operatorname{tr}$ & 1.0 & 1.0 & $\operatorname{tr}$ & 1.3 & 2.3 & 1.2 & 1.9 \\
\hline iso- $\mathrm{C}_{16: 0}$ & 1.0 & 1.6 & 1.7 & $\mathrm{ND}$ & $\operatorname{tr}$ & $\operatorname{tr}$ & 1.1 & $\operatorname{tr}$ \\
\hline iso- $\mathrm{C}_{17: 1} \omega 5 c$ & $\mathrm{ND}$ & ND & ND & $\mathrm{ND}$ & 1.4 & $\mathrm{ND}$ & ND & 1.2 \\
\hline iso- $\mathrm{C}_{17: 1} \omega 9 c$ & 4.6 & 5.0 & 4.1 & 2.0 & 2.2 & 4.0 & 2.3 & 2.2 \\
\hline \multicolumn{8}{|l|}{ Unsaturated } & ND \\
\hline $\mathrm{C}_{13: 1}$ & ND & $\mathrm{ND}$ & ND & ND & 1.1 & $\operatorname{tr}$ & $\operatorname{tr}$ & 1.1 \\
\hline $\mathrm{C}_{14: 1} \omega 5$ & $\mathrm{ND}$ & $\mathrm{ND}$ & ND & 1.0 & ND & ND & ND & $\operatorname{tr}$ \\
\hline $\mathrm{C}_{15: 1} \omega 6 c$ & 3.5 & 2.8 & 2.8 & $\operatorname{tr}$ & 4.8 & 2.5 & 1.7 & 1.6 \\
\hline $\mathrm{C}_{17: 1} \omega 6 c$ & 1.1 & 1.1 & 1.2 & $\operatorname{tr}$ & 1.7 & 1.3 & $\operatorname{tr}$ & $\operatorname{tr}$ \\
\hline \multicolumn{9}{|l|}{ Hydroxy } \\
\hline $\mathrm{C}_{15: 0} 3-\mathrm{OH}$ & 1.8 & 1.4 & 1.5 & 1.4 & 2.3 & 1.5 & 2.4 & 1.5 \\
\hline iso- $\mathrm{C}_{15: 0} 3-\mathrm{OH}$ & 3.9 & 3.8 & 3.7 & 5.0 & 3.2 & 2.9 & 5.4 & 4.1 \\
\hline $\mathrm{C}_{16: 0} 3-\mathrm{OH}$ & 1.5 & 1.8 & 2.2 & 5.4 & 2.9 & 3.0 & 2.2 & 3.7 \\
\hline iso- $\mathrm{C}_{16: 0} 3-\mathrm{OH}$ & 5.1 & 5.9 & 6.8 & 1.1 & 2.5 & 2.1 & 1.7 & 1.7 \\
\hline iso- $\mathrm{C}_{17: 0} 3-\mathrm{OH}$ & 17.5 & 19.7 & 18.3 & 28.6 & 11.6 & 18.8 & 20.4 & 14.5 \\
\hline Summed feature $3 \ddagger$ & 1.0 & 10.1 & 11.0 & 8.6 & 12.9 & 11.4 & 5.8 & 12.2 \\
\hline Unknown & 3.6 & 2.5 & 2.6 & 2.7 & 10.2 & 5.9 & 7.9 & 10.3 \\
\hline
\end{tabular}

${ }^{\star}$ Data from Nedashkovskaya et al. (2004).

$\dagger$ Data from Yoon et al. (2005).

$\ddagger$ Summed feature 3 contained iso- $\mathrm{C}_{15: 0} 2-\mathrm{OH}$ and/or $\mathrm{C}_{16: 1} \omega 7 c$, which could not be separated by GLC with the MIDI system.

genus Maribacter. Phenotypic characteristics, DNA-DNA relatedness values and protein profiles support the description of the three strains as a novel species, for which the name Maribacter forsetii is proposed.

\section{Emended description of Maribacter Nedashkovskaya et al. 2004}

This description is based on that given by Nedashkovskaya et al. (2004). Cells are rod-shaped, Gram-negative, nonflagellated and motile by gliding. Do not form endospores. Metabolism is strictly aerobic and heterotrophic. Yellow non-diffusible pigments that do not belong to the flexirubin type are produced. Cytochrome oxidase, catalase and alkaline phosphatase activities are present. Does not reduce nitrate to 


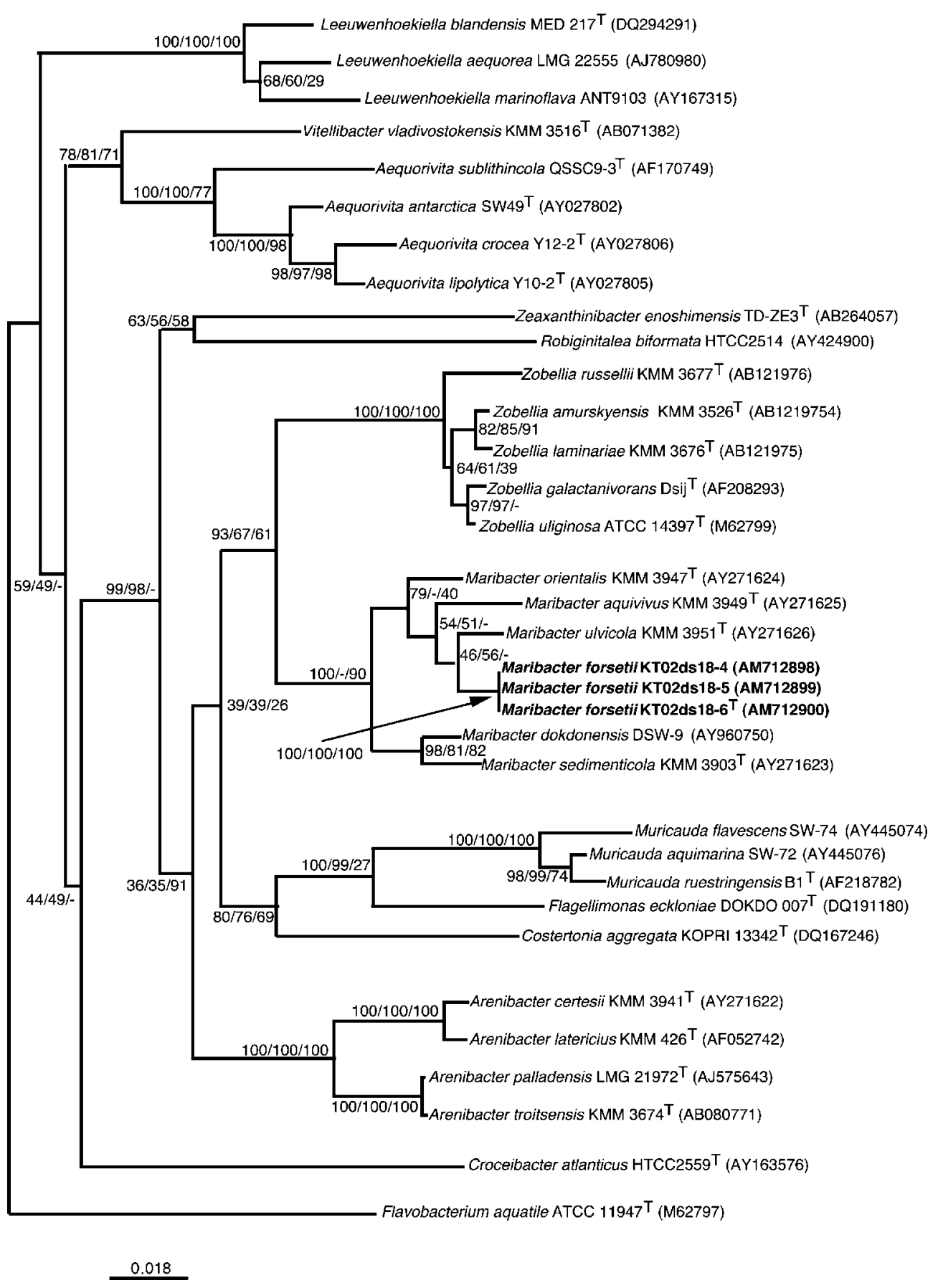

Fig. 3. Neighbour-joining tree showing the phylogenetic position of strains KT02ds18-4, KT02ds18-5 and KT02ds18-6 ${ }^{\top}$, other Maribacter species and representatives of other genera of the family Flavobacteriaceae. GenBank accession numbers are given in parentheses. Numbers at the branching points refer to the bootstrap values (500 replicates) in distance, maximumlikelihood and maximum-parsimony analyses, respectively. Dashes instead of numbers indicate that the node was not observed in the corresponding analysis. Flavobacterium aquatile ATCC $11947^{\top}$ was used as an outgroup. Bar, 0.018 substitutions per nucleotide position.

nitrite. The requirement for sodium salts is speciesdependent. Predominant cellular fatty acids are straightchain saturated, branched-chain saturated and unsaturated fatty acids iso- $\mathrm{C}_{15: 0}$, iso- $\mathrm{C}_{15: 1}, \mathrm{C}_{15: 0}$ and iso- $\mathrm{C}_{17: 0} 3-\mathrm{OH}$.
The main lipoquinone is MK-6. As determined by $16 \mathrm{~S}$ rRNA gene sequence analysis, the genus Maribacter is a member of the family Flavobacteriaceae, phylum Bacteroidetes. The type species is Maribacter sedimenticola. 


\section{Description of Maribacter forsetii sp. nov.}

Maribacter forsetii (for.set'ti.i. N.L. gen. masc. n. forsetii, of Forseti, a god in Scandinavian mythology that lived on Helgoland, the German island from where the bacterium was isolated).

Cells are non-flagellated, Gram-negative rods $0.3-0.5 \mu \mathrm{m}$ wide and 3.0-4.0 $\mu \mathrm{m}$ long, occurring singly or in pairs, with rounded ends. Cells are non-motile in liquid phase, but show active gliding motility on solid surfaces. Colonies on ZoBell 2216E agar are circular, shiny, light yellow and 1.0-3.0 $\mathrm{mm}$ in diameter after incubation for 3 days. Spreading occurs at the margins of the colonies; the extent of spreading is straindependent. Optimal growth temperature is $25^{\circ} \mathrm{C}$; growth occurs between 4 and $32{ }^{\circ} \mathrm{C}$. Optimal pH for growth is 7.5; growth occurs at $\mathrm{pH}$ 5.5-8.5, but not at $\mathrm{pH} 5.0$ and 9.0. Optimal $\mathrm{NaCl}$ concentration for growth is $2.5 \%(\mathrm{w} / \mathrm{v})$. Very weak growth occurs in the absence of $\mathrm{NaCl}$ and no growth occurs at concentrations $>9 \%(\mathrm{w} / \mathrm{v}) \mathrm{NaCl}$. Under optimal growth conditions, the doubling time is about $3.0 \mathrm{~h}$. Esterase (C4), esterase lipase (C8), leucine arylamidase, valine arylamidase, cystine arylamidase, alkaline and acid phosphatases, naphthol-AS-BI-phosphohydrolase, $\alpha$-galactosidase, $\beta$ galactosidase, $\alpha$-glucosidase and $\alpha$-chymotrypsin activities are present, but $\beta$-glucuronidase activity is absent (API ZYM). Trypsin activity is strain-dependent (negative for the type strain). Alginic acid, Tween 40 and Tween 80 are hydrolysed, but agar, $\kappa$-carrageenan, $l$-carrageenan, starch, gelatin, DNA, glycogen and inulin are not. D-Glucose, D-mannose, Dfructose, D-mannitol, D-lactose, methyl- $\beta$-D-glucoside, methyl- $\beta$-D-xyloside, $N$-acetyl-D-glucosamine, glucuronic acid, lactic acid, L-glutamic acid and L-ornithine are used as sole carbon sources, but D-arabinose, glycerol, amygdalin, acetic acid, citric acid, L-histidine, L-leucine, L-threonine and $\mathrm{L}$-phenylalanine are not. Utilization of L-serine is straindependent (negative for the type strain). Acid is produced from D-glucose, D-mannose, D-fructose, D-galactose, Darabinose, D-xylose, L-fucose, cellobiose, D-lactose, amygdalin and salicin, but not from L-arabinose, L-rhamnose and melezitose (API $50 \mathrm{CH}$ ). Acid production from gentiobiose is strain-dependent (positive for the type strain). Growth occurs in the presence of kanamycin $\left(200 \mu \mathrm{g} \mathrm{ml}^{-1}\right)$ and tetracycline $\left(10 \mu \mathrm{g} \mathrm{ml}^{-1}\right)$. Other characteristics are shown in Table 1. The DNA G + C content is $34.2-34.4 \mathrm{~mol} \%$.

The type strain, KT02ds18-6 ${ }^{\mathrm{T}} \quad\left(=\mathrm{CIP} \quad 109504^{\mathrm{T}}=\mathrm{DSM}\right.$ $\left.18668^{\mathrm{T}}\right)$, was isolated from North Sea surface water at station Kabeltonne $\left(54^{\circ} 11^{\prime} \mathrm{N} ; 7^{\circ} 54^{\prime}\right.$ E) near the island of Helgoland, Germany. Other reference strains are KT02ds18-4 (=CIP 109503=DSM 18666) and KT02ds18$5(=$ CIP $109505=$ DSM 18667).

\section{Acknowledgements}

This work was performed in the frame of "Marine Genomics Europe" NoE 7 (EC contract No. GOCE-CT-2004-505403). We thank Mirjam Czjzek for helpful discussion and critical reading of the manuscript. The authors gratefully thank Olga I. Nedashkovskaya (Pacific Institute of Bioorganic Chemistry of the Far-Eastern Branch of the
Russian Academy of Sciences, Vladivostok, Russia) for providing them with the type strains of Maribacter spp. used in this study. We also thank Annie Cavalier and Daniel Thomas (Structure et Dynamique des Macromolécules de l'UMR Interactions Cellulaires et Moléculaires, University of Rennes, Brittany, France) for transmission electron microscopy, and Jörg Wulf for expert technical assistance.

\section{References}

Abell, G. C. J. \& Bowman, J. P. (2005). Ecological and biogeographic relationships of class Flavobacteria in the Southern Ocean. FEMS Microbiol Ecol 51, 265-277.

Barbeyron, T., Kean, C. \& Forterre, P. (1984). DNA Adenine methylation of GATC sequences appeared recently in the Escherichia coli lineage. J Bacteriol 160, 586-590.

Barbeyron, T., L'Haridon, S., Corre, E., Kloareg, B. \& Potin, P. (2001). Zobellia galactanovorans gen. nov., sp. nov., a marine species of Flavobacteriaceae isolated from a red alga, and classification of [Cytophaga] uliginosa (ZoBell and Upham 1944) Reichenbach 1989 as Zobellia uliginosa gen. nov., comb. nov. Int J Syst Evol Microbiol 51, 985-997.

Bauer, M., Kube, M., Teeling, H., Richter, M., Lombardot, T., Allers, E., Würdemann, C. A., Quast, C., Kuhl, H. \& other authors (2006). Whole genome analysis of the marine Bacteroidetes 'Gramella forsetii' reveals adaptations to degradation of polymeric organic matter. Environ Microbiol 8, 2201-2213.

Benson, D. A., Boguski, M. S., Lipman, D. J., Ostell, J., Ouellette, B. F., Rapp, B. A. \& Wheeler, D. L. (1999). GenBank. Nucleic Acids Res 27, 12-17.

Bernardet, J.-F., Segers, P., Vancanneyt, M., Berthe, F., Kersters, K. \& Vandamme, P. (1996). Cutting a Gordian knot: emended classification and description of the genus Flavobacterium, emended description of the family Flavobacteriaceae, and proposal of Flavobacterium hydatis nom. nov. (basonym, Cytophaga aquatilis Strohl and Tait 1978). Int J Syst Bacteriol 46, 128-148.

Bernardet, J.-F., Nakagawa, Y. \& Holmes, B. (2002). Proposed minimal standards for describing new taxa of the family Flavobacteriaceae and emended description of the family. Int J Syst Bacteriol 52, 1049-1070.

DeLong, E. F., Preston, C. M., Mincer, T., Rich, V., Hallam, S. J., Frigaard, N. U., Martinez, A., Sullivan, M. B., Edwards, R. \& other authors (2006). Community genomics among stratified microbial assemblages in the ocean's interior. Science 311, 496-503.

Doetsch, R. N. (1981). Determinative methods of light microscopy. In Manual of Methods for General Bacteriology, pp. 21-33. Edited by P. Gerhardt, R. G. E. Murray, R. N. Costilow, E. W. Nester, W. A. Wood, N. R. Krieg \& G. B. Phillips. Washington, DC: American Society for Microbiology.

Eilers, H. (2000). Pelagische Bakteriengesellschaften in der Nordsee: Kultivierung, Diversität und in situ Dynamik. $\mathrm{PhD}$ thesis, Universität Bremen, Bremen, Germany.

Felsenstein, J. (1981). Evolutionary trees from DNA sequences: a maximum likelihood approach. J Mol Evol 17, 368-376.

Felsenstein, J. (1985). Confidence limits on phylogenies: an approach using the bootstrap. Evolution 39, 783-791.

Fitch, W. M. (1971). Toward defining the course of evolution: minimum change for a specific tree topology. Syst Zool 20, 406-416.

Galtier, N., Gouy, M. \& Gautier, C. (1996). SEAVIEW and PHYLO_WIN: two graphic tools for sequence alignment and molecular phylogeny. Comput Appl Biosci 12, 543-548. 
Gascuel, O. (1997). BIONJ: an improved version of the NJ algorithm based on a simple model of sequence data. Mol Biol Evol 14, 685-695.

Glöckner, F.-O., Fuchs, B. M. \& Amann, R. (1999). Bacterioplankton compositions of lakes and oceans: a first comparison based on fluorescence in situ hybridization. Appl Environ Microbiol 65 , 3721-3726.

Hicks, R. E., Amann, R. I. \& Stahl, D. A. (1992). Dual staining of natural bacterioplankton with 4',6-diamidino-2-phenylindole and fluorescent oligonucleotide probes targeting kingdom-level 16S rRNA sequences. Appl Environ Microbiol 58, 2158-2163.

Hugh, R. \& Leifson, E. (1953). The taxonomic significance of fermentative versus oxidative metabolism of carbohydrates by various negative bacteria. J Bacteriol 66, 24-26.

Ivanova, T. L., Turova, T. P. \& Antonov, A. S. (1988). DNA-DNA hybridization studies on some purple non sulfur bacteria. Syst Appl Microbiol 10, 259-263.

Johnson, J. L. (1984). DNA reassociation and RNA Hybridization of bacterial nucleic acids. In Bergey's Manual of Systematic Bacteriology, vol. 1, pp. 8-11. Edited by N. R. Krieg \& J. G. Holt. Baltimore, USA: Williams \& Wilkins.

Kane, M. D., Poulsen, L. K. \& Stahl, D. A. (1993). Monitoring the enrichment and isolation of sulfate-reducing bacteria by using oligonucleotide hybridization probes designed from environmentally derived 16S rRNA sequences. Appl Environ Microbiol 59, 682-686.

Kimura, M. (1980). A simple method for estimating evolutionary rates of base substitutions through comparative studies of nucleotide sequences. J Mol Evol 16, 111-120.

Kirchman, D. L. (2002). The ecology of Cytophaga-Flavobacteria in aquatic environments. FEMS Microbiol Ecol 39, 91-100.

Kristjánsson, J. K., Hjörleifsdóttir, S., Marteinsson, V. T. \& Alfredsson, G. A. (1994). Thermus scotoductus, sp. nov., a pigmentproducing thermophilic bacterium from hot tap water in Iceland and including Thermus sp. X-1. Syst Appl Microbiol 17, 44-50.
Nedashkovskaya, O. I., Suzuki, M., Vysotskii, M. V. \& Mikhailov, V. V. (2003). Arenibacter troitsensis sp. nov., isolated from marine bottom sediment. Int J Syst Evol Microbiol 53, 1287-1290.

Nedashkovskaya, O. I., Kim, S. B., Han, S. K., Lysenko, A. M., Rohde, M., Rhee, M.-S., Frolova, G. M., Falsen, E., Mikhailov, V. V. \& Bae, K. S. (2004). Maribacter gen. nov., a new member of the family Flavobacteriaceae, isolated from marine habitats, containing the species Maribacter sedimenticola sp. nov., Maribacter aquivivus sp. nov., Maribacter orientalis sp. nov. and Maribacter ulvicola sp. nov. Int J Syst Evol Microbiol 54, 1017-1023.

Reichenbach, H., Kleinig, H. \& Achenbach, H. (1974). The pigment of Flexibacter elegans: novel and chemosystematically useful compounds. Arch Microbiol 101, 131-144.

Saitou, N. \& Nei, M. (1987). The neighbor-joining method: a new method for reconstructing phylogenetic trees. Mol Biol Evol 4, 406-425.

Sasser, M. (1990). Identification of bacteria by gas chromatography of cellular fatty acids, MIDI Technical Note 101. Newark, DE: MIDI Inc.

Schut, F., De Vries, E. J., Gottschal, J. C., Robertson, B. R., Harder, W., Prins, R. A. \& Button, D. K. (1993). Isolation of typical marine bacteria by dilution culture growth maintenance and characteristics of isolates under laboratory conditions. Appl Environ Microbiol 59, 2150-2159.

Smibert, R. M. \& Krieg, N. R. (1981). General characterization. In Manual of Methods for General Microbiology, pp. 409-443. Edited by P. Gerhardt, R. G. E. Murray, R. N. Costilow, E. W. Nester, W. A. Wood, N. R. Krieg \& G. B. Phillips. Washington, DC: American Society for Microbiology.

Stackebrandt, E. \& Goebel, B. M. (1994). Taxonomic note: a place for DNA-DNA reassociation and $16 \mathrm{~S}$ rRNA sequence analysis in the present species definition in bacteriology. Int J Syst Bacteriol 44, 846-849.

Yoon, J.-H., Kang, S.-J., Lee, S.-Y., Lee, C.-H. \& Oh, T.-K. (2005). Maribacter dokdonensis sp. nov., isolated from sea water off a Korean island, Dokdo. Int J Syst Evol Microbiol 55, 2051-2055.

ZoBell, C. E. (1941). Studies on marine bacteria. I. The cultural requirements of heterotrophic aerobes. J Mar Res 4, 41-75. 